\title{
Student Internship Experience on Career Selection Survey: Vocational Education Accounting Program
}

\author{
Birawani Dwi Anggraeni ${ }^{{ }^{*}}$ \\ ${ }^{1}$ Accounting Laboratory, Vocational Education Program, Universitas Indonesia \\ *Email: beerawani@gmail.com
}

\begin{abstract}
This study aims to assess the experience during the apprenticeship of student career selection. The research design uses a questionnaire and a sample of the students of the class of 2015 who have completed a 3-month to 4-month apprenticeship with either KAP or another company in one of three concentrations: financial accounting, public sector accounting, and accounting information systems technology. The questionnaire acquired the primary data from students after they completed the internship program. The results of this field survey indicate that most of students had a positive internship experience, and this finding provides a positive signal regarding the selection of their profession in the field of accounting.
\end{abstract}

Keywords: apprenticeship program, professional career selection, accounting

\section{Introduction}

Indonesia and its neighbors in the Association of Southeast Asian Nations (ASEAN) have entered into an ASEAN Economic Community (MEA) agreement whereby the workforce of each country can contribute to other countries. Accountants are in demand and have access to the free market such that required graduates are ready to work in their field. The demands of the Ministry of Manpower has increased the needs of industrial human resources by focusing on the preparation of one million workers until 2019, in line with presidential Directive no. 9 of 2016. This Presidential Instruction grants 12 ministries and one institution the right to develop vocational education in Indonesia, where it is expected to be a solution to the production of competent, competitive, and professionally prepared human resources. Indonesia must have resources that can overcome its problems and increase industrial productivity (Red: Agus Yulianto, 2017).

The apprenticeship program in vocational education provides an alternative to improving the quality and experience for students through the experimental experience of the students regarding real-world practice in certain fields because it is expected to link and match with industry and government programs. Vocational education emphasizes the development of theoretical practice. The existence of an adaptation process between students and real industry will become shorter because students can immediately understand and perform work duties according to industry requirements.

One method used to gain experience in the workplace is internship programs. These programs allow the workplace to discover new graduates who have extensive knowledge and skills in various fields such as communication, presentation, and analytic thinking that they can apply to discussions and interactions with friends and colleagues. In today's classroom environment, students do not have this opportunity. The classroom environment does not reflect the professional atmosphere and the interaction of businesses in the world of work. The internship program is a link between the world of work and the world of education.

Students looking for the appropriate career choice experience anxiety when they are concerned over their lack of understanding of the job. Apprenticeships provide direction for career choices over a limited time and resources such as experience (Kin Tong and Tong, 2012). The experience students gain in internships is important for their future. The experience that students receive during internships develops skills they can apply in their chosen profession. During apprenticeships, students focus on improving skills, techniques, and responsibilities as workers, providing them a complete picture of the duties required for a given career. Internships may also increase awareness of environmental work. A professional learning experience in the work environment is available in organizations outside the university (Furco, 1996). Internship programs are designed to promote the learning process to prepare students to enter the workforce as a professional-level employee who can work independently (Billett, 2009). Career uncertainty is a major precursor to career uncertainty because students facing uncertainty often become hesitant about their careers (Jordaan, Smithard, and Burger, 2009). Internships can of- 
fer mutual benefits for students and employers where cheap labor is available with fresh ideas for workplace and valuable work experiences for students. Vocational behavior is "any interaction between an individual and himself an environment significantly related to preparation, participation in, or retirement from work (Super, 1957).”

Awareness is gained from students' internship experiences whereby they can confirm their expectations of working in a particular profession or industry in three ways. First, the apprenticeship experience provides clarification for the students over their interest in becoming a worker as part of their career path (McCarthy and McCarthy, 2006; Rothman, 2007; Moghaddam, 2011). Second, students gain a relative picture of being a worker because they expect their future to have a balance between lifestyle and work life (Hiltebeitel, Leauby, and Larkin, 2000a), which has proven to be important for the Y cohort generation. Third, the apprenticeship assists the student in personalized reflection regarding success in work or industry (Lord, Sumrall, and Sambandam, 2011). Apprenticeship programs also prepare students to apply the knowledge they gained in the classroom directly to the workplace based on the research conducted. Practice in the work world cannot normally be provided in normal classes (Beard and Morton, 1999a).

Practitioners and academics have demonstrated that a relationship between career and internship and work experience is a critical part of and the basis for informative decisions considered when choosing a career (Gault, Redington, and Schlager, 2010). The results of a survey on internship where the appraisal was that the apprenticeship did not provide experience helpful in determining a career path or increase job opportunities (Moghaddam, 2011) is more important for the benefit of an internship career (Swanson and Tomkovick, 2012); additionally, no difference was observed in their confidence in careers according to their work after graduation compared with peers who did not complete an internship (Callanan and Benzing, 2004).

Similarly, for students who complete the internship in private, a positive attitude of postapprentice behavior is significantly related to their attitude before experience ( $\mathrm{Liu}, \mathrm{Xu}$, and Weitz, 2011). Students remain helpful in determining the direction of their careers, although the experience during their internship neither matched their expectations (Beard and Morton, 1999b) nor helped them avoid unfavorable career paths.

The specific type of work in an organization and industry that contributes to the development of a positive attitude toward work and industry can be learned by students as an apprentice (Liu, Xu, and Weitz, 2011). Additionally, self-employment decisions can be determined by other factors such as students' interests, values, abilities, or lifestyle.

New workers who have completed internships expressed dissatisfaction compared with workers who had not participated in an internship program (Hiltebeitel, Leauby, and Larkin, 2000b). Some students perceive internships as a means of gaining employment (Cannon and Arnold, 1998) and effectively improve their skills such as those applicable to teamwork and problem-solving. This experience is what they regard as compensation for the apprenticeship (Marshall and Mill, 1993). In addition, workplaces that provide internships can identify potential employees. Workplaces and campuses can enhance cooperation in enhancing cooperative relationships and improve coordination to improve a company's image in the community.

Students take the actions necessary to ensure that the internship program matches their career objectives and goals, establishes logistical arrangements, and evaluates the experience. Additionally, accounting program administrators are aware of apprentices' characteristics because of their role within the university and within the business community that employs interns. Most of the questions in the survey relate to the accounting program, such as the classification of eligible students, number of participants, process for securing internships, availability of academic credits, postapprenticeship requirements, and their impact on subsequent academic performance. Such knowledge and responsibility generally reside in the administrators of the accounting program. The hard and soft skills among accounting graduates must be improved because of the increasing competition and the career's high mobility in the global market. Hard skills refer to technical aspects related to data and administration skills. Soft skills are defined as "interpersonal, human, person or behavioral skills necessary to apply technical skills and knowledge in the workplace" (Weber et al., 2009). Weber et al. (2009) explained that a graduate has soft skills when they demonstrate the ability to communicate with others and understand others. (2)

More complex learning concepts and more meaningful learning approaches indicate a richer learning experience (Marton and Booth 1997; Prosser and Trigwell 1999). The quality of student learning experiences can be attributed to variations in learning outcomes to identify means in which a student learning experience may be established to support the achievement of high-quality results (Entwistle 1997; Marton and Säljö 1976; Prosser and Trigwell (4)

Internships may also affect how a student feels about the accounting profession in general, and she or he may choose to leave the industry for other related fields such as finance or economics. Internship activities provide experiences that determine the career of students. The internship program is one part of the curriculum that must be executed by sixth-semester accounting students and is conducted for 3-4 months in an accounting entity, namely, a public accounting firm (KAP) and the company. This research explored the impact of apprentice- 
ship activities in a KAP by accounting students in Semester 5 at a KAP. This is because $90 \%$ of vocational student apprenticeships for vocational education in a KAP are spread across Jakarta, Depok, and Bekasi, where students are junior assistant auditors. Thus, this study attempted find an answer to whether a link exists between the students' apprenticeship program and their career selection. The research question was posed to help determine the impact of students' internship experience on their professional career choices.

This research attempted to clearly describe the information obtained from the survey results of the students to answer the following questions: what experience did the students get during the internship? and How did the internship affect students' career decision?

\section{Method}

Research design. This research used a descriptive research approach.

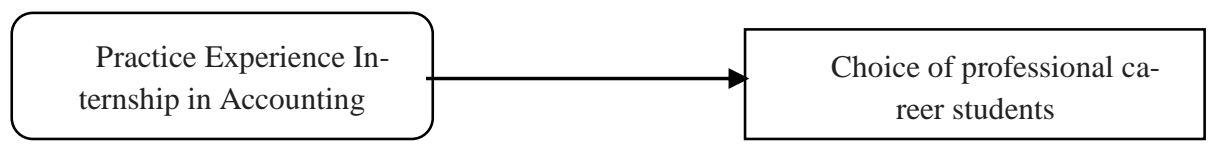

Figure 1. Model research framework

Based on Figure 1, this study aimed to determine the effect of internship experience in the field of accounting on career choice. The purpose of this research was to understand the relationship or interaction between the experience of an internship with career selection. This research was conducted in a Vocational Education Program after the internship period was completed, starting on May 06, 2018.

Sixth-semester students were required to undertake the internship specified by the accounting study program. Students may request the study program find an apprenticeship in either KAP or non-KAP. Whether the place of apprenticeship influences the intern experience is a notable factor. Selection of apprenticeship placement was based on student request. The average student internship period was from January to March or April, depending on the agreement with the workplace.

This research used a survey research method (survey research method), which was analytic (explanatory study), and the main analysis was performed on the data obtained by respondents' answers to the questions.

This study used a case study in vocational education accounting as the main method of the research. According to Simon (2014), case studies have limitations but also characteristics similar to observational studies. An understanding of the student internship experience can be obtained through a case study. The population is students of accounting in 2015, that is, as many as 150 students. Notably, the required sample is 110 students.

The population was the object of research and a target to obtain and collect data. The sample was part of the individual studied from individual sample samples. A good sample is a sample that has a population or representative means to describe the state of the population. For the study, the entire study population was used, and all research units became the research sample. This method is called total population. Additionally, research that does not use the entire study population applies a sampling technique called (Zaluchu, 2012). Samples were taken using probability sampling where sampling would provide equal opportunity for each member of the population to be sampled. This study used simple random sampling (the simplest technique), in which samples were taken randomly from a population regardless of population level. According to Cooper and Schindler (2006: 421), simple random sampling is a sampling method in which each element of the population has an equal opportunity to be selected as a sample member.

According to Slovin (riduwan, 2,005:65) $\mathrm{n}=\mathrm{N} / \mathrm{N}$ (d) $2+1$; thus, if the student class of 2015 has as many as 150 students, the error rate is $5 \%$, and the number of samples used is $n=150 /(150 \times 0.052)+1=109$ rounded to 110 samples; thus, the sample in this study was a population of 150 students that had a $95 \%$ confidence level of 110 students.

\section{Results and Discussion}

The quality of the students at the internship and how they worked as apprentices determine which students would continue as a profession to be selected. Asatisfying internship experience results in the student continuing 
the internship program beyond the initial agreement. Respondent data include age, gender, place of internship, duration of apprenticeship, final GPA, and concentration in study program (financial accounting, public sector accounting, and accounting information system technology). The question used in this study refers to a similar study conducted by Brenda entitled Student Perceptions of Public Accounting Internships: A case study in 2017. Research questions were divided into two types: open and closed questions. Open questions consisted of seven questions to assess the background of the place of apprenticeship. For closed questions, Likert scale 1 through 4 was used to assess the student experience during the internship.

Primary data collection was derived from questionnaires created by the researchers. The results of the questionnaire are the data obtained from the answers given by the students. Secondary data were from the academic part of the apprenticeship value obtained by the students from the internship.

As many as 103 questionnaires were filled out; however, only 96 had valid data. The respondents' data are as follows.

Table 1 Recapitulation of respondent data

\begin{tabular}{|l|l|l|l|}
\hline No & Respondent's data & Total \\
\hline 1 & Gender & Male & 35 \\
& & Female & 61 \\
\hline 2 & apprenticeship place & KAP & 79 \\
& & non-KAP & 17 \\
\hline 3 & concentration & AK & 33 \\
& & asp & 33 \\
& & TSI & 30 \\
\hline 4 & GPA & $2.5-3$ & 9 \\
& & $3.01-3.5$ & 54 \\
& & more than 3.5 & 33 \\
\hline
\end{tabular}

Table 2 Information on characteristics of internships

\begin{tabular}{|l|l|}
\hline Characteristics & Frequency \\
\hline Duration of the internship period: & \\
3 months & 63 \\
4 months & 31 \\
More than 4 months & 2 \\
\hline Daily wage apprenticeships: & \\
Not paid & 10 \\
Rp 30.000-Rp75.000/day & 32 \\
Rp75.001-Rp100.000/Day & 48 \\
More than Rp100.000/Day & 6 \\
\hline Number of hours worked per week: & \\
0-35 hrs & 3 \\
36-40 hrs & 73 \\
More than 40 hrs & 20 \\
\hline Formal training before apprenticeship: & \\
Yes & 53 \\
No & 42 \\
\hline
\end{tabular}

Table 3 List of Questions

\begin{tabular}{|l|l|l|l|}
\hline No & Questions & $\begin{array}{l}\text { Result of } \\
\text { mean }\end{array}$ & $\begin{array}{l}\text { Percentage } \\
\text { agree }\end{array}$ \\
\hline 1 & $\begin{array}{l}\text { the company/KAP where I apprenticed provided clear } \\
\text { guidance on what I should do }\end{array}$ & 2.948 & $79.1 \%$ \\
\hline 2 & I am involved in a real job & 3.313 & $92.6 \%$ \\
\hline 3 & I learned a lot about how accounting works & 3.198 & $87.5 \%$ \\
\hline 4 & I do the work that suits my level of education & 3.094 & $90.7 \%$ \\
\hline 5 & I feel comfortable asking questions if I find it difficult & 3.333 & $91.7 \%$ \\
\hline 6 & I got help when I needed it & 3.385 & $98 \%$ \\
\hline 7 & the result of my work as an apprentice is valued by the & 3.323 & $94.8 \%$ \\
\hline
\end{tabular}




\begin{tabular}{|l|l|l|l|}
\hline No & Questions & $\begin{array}{l}\text { Result of } \\
\text { mean }\end{array}$ & $\begin{array}{l}\text { Percentage } \\
\text { agree }\end{array}$ \\
\hline & company/KAP & & \\
\hline 8 & I gained valuable experience during my apprenticeship & 3.406 & $93.7 \%$ \\
\hline 9 & the internship fulfilled my expectations & 3.135 & $88.5 \%$ \\
\hline 10 & $\begin{array}{l}\text { my career path in accounting is more determined after my } \\
\text { apprenticeship }\end{array}$ & 3.135 & $87.5 \%$ \\
\hline
\end{tabular}

Regarding the questionnaire results, as many as 10 questions were on students' internship experience either in a KAP or non-KAP for 3-4 months. Based on the table, students felt the various experiences during the internship. Students had a good perception and as much as $79.1 \%$ agreed that during their internship they got a clear direction, and $19.4 \%$ disagree. Students experienced real work experience, as much as $92.6 \%$, and the remainder did feel not involved in the actual work. Students agreed they experience much work related to accounting $87.5 \%$. Students also agreed, $90.7 \%$, that during their internship, they did work based on their level of education. Students also felt comfortable asking questions of their seniors or superiors when reporting $91.7 \%$ of the field difficulties. Students felt that during their apprentice apprenticeship, they directly provided $98 \%$ assistance. During the internship, the students, 94.8, felt that their work was valued. Students, 93.7\%, had a valuable experience during apprenticeship. The results of the survey of students also indicated that the internship experience had fulfilled their expectations. After passing an internship, they generally claimed that career choices in accounting were increasingly convinced after their internship. The results of the survey of accounting students who mostly apprenticed in KAP shows the results of career choice to be an accountant was as much as $28 \%$; auditor $45 \%$, civil servants $7 \%$, 7businessmen $7 \%$, and other such as management trainee $12.5 \%$.

Table 4 List of professions after internships

\begin{tabular}{|l|l|l|}
\hline No & Profession & Frequency \\
\hline 1 & Accountant & 27 \\
\hline 2 & auditor & 43 \\
\hline 3 & civil servants (PNS) & 7 \\
\hline 4 & businessman & 7 \\
\hline 5 & others & 12 \\
\hline
\end{tabular}

\section{Conclusion}

This study aimed to understand the experience of student internship on their selection of career, especially in accounting. This study used questionnaires as a tool to conduct a survey of the accounting student class of 2015 who had completed an apprenticeship for 3-4 months, and most of the internships were in a KAP as a junior auditor. The results obtained indicate that most of students agree that their experience started from the direction of the apprenticeship, followed by the guidance during adversity, the workload given in accordance with their education, and the results of their work being respected by the workplace. Thus, most of the students choose a career in accounting as an auditor or corporate accountant. This finding is in line with research conducted by Brenda (2017) and Furco (1996), Billet (2009), and Cunningham (2005). The presence of clear directions during the internship provides an overview of the work to be chosen, which supports this study.

However, some students claimed that their careers are not in the field of accounting but as civil servants or in other positions, such as management trainees, because they feel uncomfortable working in the field of accountants because according to their field of accounting, this field is not their field of expertise. These results are consistent with Beard and Morton (1999) and Templeton (2012), where apprenticeship experience did not help in determining career.

The results of this simple study provide direction for the improvement of the internship program with the industry by designing the training to be more directed by the needs of a workplace that has competence, competitiveness, and the ability to work professionally. Good synergy between the campus, internship, and student workshops would provide a positive internship experience and produce graduates ready to work in their fields; in this case, the field is accounting.

This study also serves as a basis for further research because this survey study only collected data using a questionnaire, further research can capture in-depth the main characteristics that help respondents determine 
their career choices. The current digital era of industrial revolution 4.0 is evolving and emphasizes the development of the "Education Industry" (teaching industry); thus, it must be studied more deeply regarding what type of industry internship experience produces graduates who have the competence and which professionals can provide valuable experiences for students determining their career options because they are in that era because today's students are millennials or digital natives.

An additional limitation of this study was our use of only in location and one field of work; thus, the research cannot be used as a general reference to determine the careers of students.

From the results of the present study, it can be concluded that habitual mouth breathing among children is associated with specific types of malocclusion, including class II division 1, anterior open bite, and/or posterior crossbite. The temporal history of mouth breathing, especially durations of more than 3 years, may influence malocclusion establishment.

\section{Acknowledgment}

In the name of God, the Most Merciful and the Merciful. Praise be to Allah who has provided ease in this writing through the guidance of my colleague Dr Budiman in completing this simple paper. Also, I am also grateful for the academic accounting for its assistance in collecting questionnaire data as primary data in this survey research.

\section{References}

Beard, F., \& Morton, L. (1999). Effects of internship predictors on successful field experience. Journalism and Mass Communication Educator, 42-53.

Billett, S. (2009). Realizing the educational worth of integrating work experiences in higher education. Studies in Higher Education, 34(7), (827-843). doi: 10.1080/03075070802706561

Callanan, G., \& Benzing, C. (2004). Assessing the role of internships in the career-oriented employment of graduating college students. Education + Training, 46(2), 82-89. doi: 10.1108/00400910410525261.

Cannon, J. A., \& Arnold, M. J. (1998). Student expectations of collegiate internship programmes. Journal of Education for Business, 73(4), 202-205. doi: 10.1080/08832329809601630.

Furco, A. (1996). Service-learning: A balanced approach to experiential education. In B. Taylor and Corporation for National Service (Eds.), Expanding boundaries: Serving and learning (pp. 2-6). Washington, DC: Corporation for National Service.

Gault, J., Redington, J., \& Schlager, T. (2010). Undergraduate business internships and career success: Are they related? Journal of Marketing Education, 22-45.

Hiltebeitel, K. M., Leauby, B. A., \& Larkin, J. M. (2000a). Job satisfaction among entry-level accountants. CPA Journal, 70(5), 76-79.

Jordaan, Y., Smithard, C., \& Burger, E. (2009). Comparing levels of career indecision among selected honours degree students at the University of Pretoria. Meditari Accountancy Research, 17(2), 85-100. doi: $10.1108 / 10222529200900013$

Kin Tong, D. Y., \& Tong, X. F. (2012). Negative opinion of company environment mediates career choice of Accountancy students. Education + Training, 54(6), 534-557, https:// doi.org/10.1108/00400911211254307. doi: $\underline{10.1108 / 00400911211254307}$

Liu, Y., Xu, J., \& Weitz, B. A. (2011). The role of emotional expression and mentoring in internship learning. Academy of Management Learning and Education, 10(1), 94-110. doi: 10.5465/amle.10.1.zqr94.

Lord, D. R., Sumrall, D., \& Sambandam, R. (2011). Satisfaction determinants in business internships. Interdisciplinary Journal of Contemporary Research in Business, 2(10), 11-22.

Marshall, I., \& Mill, M. (1993). Using student-driven learning contracts in work-based learning and with small businesses. In J. Stephenson \& M. Laydock (Eds.), Using LearningContracts in higher education (pp. 115-121). London: Kogan Page.

McCarthy, P. R., \& McCarthy, H. M. (2006). When case studies are not enough: Integrating experiential learning into business curricula. Journal of Education for Business, 81(2), 201-204. doi: 10.3200/JOEB.81.4.201-204.

Moghaddam, J. M. (2011). Perceived effectiveness of business internships: Student expectations, experiences and personality traits. International Journal of Management, 28(4), 287-303

Rothman, M. (2007). Business students' evaluation of their internships. Psychological Reports, 101(1), 319-322. doi: 10.2466/pr0.101.1.319-322.

Super, D. E. (1957). The psychology of careers. New York, NY: Harper \& Brothers.

Swanson, S. R., \& Tomkovick, C. (2012). Marketing internships: How values and search strategies differ across the studentemployer dyad. Marketing Education Review, 22(3), 251-262. doi: 10.2753/MER1052-8008220305. 
Weber, M. R., Finley, D. A., Crawford, A., \& Rivera, D. J. (2009). An exploratory study identifying soft skill competencies in entry-level managers. Tourism and Hospitality Research, 9(4), 353-361. doi: 10.1057/thr.2009.22.

http://republika.co.id/berita/jurnalisme-warga/kabar/17/02/05/okw2ky396-pendidikan-vokasi-untuk-menghasilkan-sdmyang-berdaya-saing. Red: Agus Yulianto. Ahad 05 Februari 2017 13:41 WIB (diakses tanggal 6 Mei 2018). 